\title{
N-Acetylcysteine Promotes DNA Repair after Genotoxic Damage Induced by Copper Sulphate in Human Lymphocytes
}

\author{
Edgardo Becerra, Karla Padilla, Laura C Berumen and Guadalupe García Alcocer* \\ Faculty of Chemistry, Autonomous University of Querétaro, University Center, Mexico \\ *Corresponding author: Guadalupe García Alcocer, Faculty of Chemistry, Autonomous University of Querétaro, \\ University Center, Mexico
}

\section{ARTICLE INFO}

Received: 画 July 16, 2020

Published:

Citation: Edgardo B, Karla P, Laura C Berumen, Guadalupe García A. N-Acetylcysteine Promotes DNA Repair after Genotoxic Damage Induced by Copper Sulphate in Human Lymphocytes. Biomed J Sci \& Tech Res 29(2)-2020. BJSTR. MS.ID.004776.

Keywords: Antioxidant; Genotoxicity; Mutation; Oxidation; Redox
ABSTRACT

DNA damage may be induced by high reactive oxygen species levels and is related to cancer, amongst many diseases. Previous studies have shown that the excess of copper in cells increases the reactive oxygen species. Moreover, oxidative stress also diminishes the DNA repair enzymes, activity, hence, increasing cancer risk. There are existing reports about the role of $\mathrm{N}$-acetylcysteine in DNA protection related to its antioxidant activity; however, its role in DNA repair has not been studied. In the present work, the DNA repair by $\mathrm{N}$-acetylcysteine was analyzed through the comet assay in human lymphocytes after inducing genotoxicity by means of copper sulphate. The gathered data indicates that $\mathrm{N}$ - acetylcysteine is innocuous at $1000 \mu \mathrm{M}$ and significantly reduced the DNA damage in human lymphocytes, which were previously treated with $\mathrm{Cu}_{2} \mathrm{SO}_{4}$, while $\mathrm{N}$-acetylcysteine exerted an adjuvant effect on the repair of DNA in human lymphocytes.

Abbreviations: ROS: Reactive Oxygen Species; DSBs: Double-Strand Breaks; NAC: $\mathrm{N}$-Acetylcysteine

\section{Introduction}

The excess of many chemical substances in humans, such as copper has been reported to induce DNA damage and trigger cancer development [1]. The main reason for copper involvement in DNA damage has been associated to the increase of reactive oxygen species (ROS) [2]. ROS can induce DNA damage by means of two mechanisms: generation of DNA mutations, usually base pair substitutions, and DNA cleavage, where single strands breaks induce DNA instability [3]. The comet assay enables detection of the DNA double-strand breaks (DSBs) and it has been used to evaluate copper genotoxicity caused by oxidative damage in several plants, animals $[4,5]$ and human cells as lymphocytes [6,7]. The DNA damage induced by ROS, can be decreased by the antioxidant action of N-acetylcysteine (NAC). Previous studies have reported the effect of NAC on DNA protection from ROS damage [8]. Xie, et al. evidenced the DNA protection effect of NAC against radiation harm on mice lymphocytes [9]. On the other hand, Ansari, et al. reported that NAC protects DNA from oxidative damage in rat intestine [10].
Additionally, NAC has been well established, such as a cytoprotective drug with an antioxidant effect as well as antiinflammatory functions [11]. Therefore, NAC exerts a fundamental roll in DNA protection, which may act as a chemioprotective agent to some diseases [12]. However, if DNA damage already exists, it needs to be repaired because the cell repair system is diminished due to oxidative lesions and this may increase the risk of cancer [13]. Due to the fact that DNA damage can lead towards the initiation of cancer progression, DNA damage repair proteins are present in cells in order to maintain the genome integrity. DNA damage is repaired in two manners: first, lesions are recognized for specialized proteins and second, multiple enzymes are involved in the repair process [14]. Certain studies associate oxidative stress condition with a restricted activity or inactivated enzymes involved in DNA damage repair [15]. Oxidative stress has been reported as the most frequent cause of DNA damage, such being the reason for the NAC to have a protective effect; yet could it be possible that 
NAC excerts a repairing effect on DNA? The comet assay procedure was followed in order to study the DNA repair effect of the NAC, it was used blood $(5 \mathrm{ml})$ from a healthy subject for four times to obtain lymphocytes, afterwards the cells were treated with copper sulphate and NAC.

\section{Objectives}

In the present work, we performed the following objectives:

1) To determine the DNA damage caused by copper sulphate.

2) To determine the N-acetylcysteine innocuity/damage to DNA.

3) To evaluate the effect of $\mathrm{N}$-acetylcysteine on DNA repair.

\section{Material and Methods}

\section{Peripheral Blood Extraction}

Peripheral blood was obtained four times from the same healthy subject by venipuncture $(5 \mathrm{ml})$ in a blood sample tube containing EDTA as anticoagulant and it was diluted 1:1 with PBS $1 \mathrm{X}$. We isolated the lymphocytes from the same subject to test the effect of $\mathrm{Cu}_{2} \mathrm{SO}_{4}$ and NAC. This procedure was done according to the Mexican bioethics NOM-012-55A3-2012 and following the Helsinki declarations protocol.

\section{Lymphocyte Isolation}

Two parts of blood-PBS (1:1) mixture were added to three parts of Ficoll paquepremium. The tube was centrifuged for $30 \mathrm{~min}$ at $3500 \mathrm{rpm}$, and then the white coat was separated and resuspended in PBS at $5 \mathrm{ml}$ final volume. The lymphocytes were centrifuged for 5 min at $2500 \mathrm{rpm}$ and the supernatant was removed. The pellet was resuspended into $1 \mathrm{~mL}$ RPMI-1640 medium containing 10\% of FBS. Lymphocytes were incubated at $37^{\circ} \mathrm{C}, 5 \% \mathrm{CO}_{2}$.

\section{Test Material Treatment}

Immediately, after the lymphocyte's isolation, $2 \times 10^{4}$ cells per $100 \mu \mathrm{L}$ of PBS were used to test the effect of $\mathrm{Cu}_{2} \mathrm{SO}_{4}$ and NAC. Each tested material was added to the lymphocyte's samples (Table 1) and were incubated at $37{ }^{\circ} \mathrm{C}$ for 2 hours. After the treatment, the cells were centrifuged for 5 minutes at $3000 \mathrm{rpm}$, afterwards, the lymphocytes pellet was resuspended in $100 \mu \mathrm{L}$ of PBS accordingly, and $10 \mu \mathrm{L}$ were removed for a trypan blue viability test, additionally, a comet assay was conducted on the samples.

Table 1: Experimental design for the detection of $\mathrm{CuSO}_{4}$ genotoxicity and NAC innocuity/genotoxicity in human lymphocytes.

\begin{tabular}{|c|c|c|c|c|c|c|c|c|}
\hline Groups & PBS 1X & $\begin{array}{c}\mathrm{H}_{2} \mathrm{O}_{2} \\
200 \mu \mathrm{M}\end{array}$ & $\begin{array}{l}\mathrm{Cu}_{2} \mathrm{SO}_{4} \\
50 \mu \mathrm{M}\end{array}$ & $\begin{array}{c}\mathrm{Cu}_{2} \mathrm{SO}_{4} \\
100 \mu \mathrm{M}\end{array}$ & $\begin{array}{c}\mathrm{Cu}_{2} \mathrm{SO}_{4} \\
200 \mu \mathrm{M}\end{array}$ & $\begin{array}{c}\text { NAC } \\
500 \mu \mathrm{M}\end{array}$ & $\begin{array}{c}\text { NAC } \\
1000 \mu \mathrm{M}\end{array}$ & $\begin{array}{c}\text { NAC } \\
1500 \mu \mathrm{M}\end{array}$ \\
\hline $\begin{array}{c}\text { Negative } \\
\text { Control }\end{array}$ & + & - & - & - & - & - & - & - \\
\hline $\begin{array}{l}\text { Positive } \\
\text { Control }\end{array}$ & - & + & - & - & - & - & - & - \\
\hline $\mathrm{Cu}_{2} \mathrm{SO}_{4} 1$ & - & - & + & - & - & - & - & - \\
\hline $\mathrm{Cu}_{2} \mathrm{SO}_{4} 2$ & - & - & - & + & - & - & - & - \\
\hline $\mathrm{Cu}_{2} \mathrm{SO}_{4} 3$ & - & - & - & - & + & - & - & - \\
\hline NAC 1 & - & - & - & - & - & + & - & - \\
\hline NAC 2 & - & - & - & - & - & - & + & - \\
\hline NAC 3 & - & - & - & - & - & - & - & + \\
\hline \multicolumn{9}{|l|}{ *NAC/ } \\
\hline $\mathrm{Cu}_{2} \mathrm{SO}_{4}$ & - & - & - & - & + & - & + & - \\
\hline
\end{tabular}

Note: *Group NAC/ $\mathrm{Cu}_{2} \mathrm{SO}_{4}$ was incubated $2 \mathrm{~h}$ with $\mathrm{Cu}_{2} \mathrm{SO}_{4} \mu \mathrm{M}$ and then $2 \mathrm{~h}$ with $\mathrm{NAC} 1000 \mu \mathrm{M}$.

\section{Comet Assay Alkaline Version}

The agarose microgels were prepared as follows: the first layer was prepared with $50 \mathrm{~mL}$ of agarose normal melting point at 1.0 percent and distributed along a slide previously degreased with ethanol. For the distribution of the agarose, a rectangular glass cover was used to obtain a homogeneous layer and removed after the agarose solidified. The second layer consisted of $90 \mathrm{~mL}$ mixture of low melting agarose (ABPF) $0.5 \%$ and lymphocyte suspension (mix of $100 \mu \mathrm{L}$ of the lymphocytes suspension and $100 \mu \mathrm{L}$ of ABPF), the agarose-cell mixture was distributed on the first layer with a coverslip. Afterwards, it was allowed to solidify at $4{ }^{\circ} \mathrm{C}$ for $5 \mathrm{~min}$, and then the coverslip was removed. The third layer was prepared with $90 \mathrm{~mL}$ of ABPF, distributed on the second agarose layer with the aid of a coverslip, and it was allowed to solidify at $4{ }^{\circ} \mathrm{C}$ for $5 \mathrm{~min}$. From this instance on, the work was conducted in a darkroom to prevent light damaged on the DNA after the cell lysis. The agarose microgels were immersed in $50 \mathrm{~mL}$ of lysis solution $\left(4^{\circ} \mathrm{C}\right)$ for $1.5 \mathrm{~h}$ allowing cell lysis.

The microgels were washed with 1X PBS and placed horizontally in the electrophoresis chamber; the chamber was filled with running buffer (10N NaOH, $300 \mathrm{mM}$ EDTA), pH of 13.0, and allowed to stand for 20 min to allow the unwinding of the DNA. Electrophoresis was 
conducted under the following conditions: $25 \mathrm{~V}, 300 \mathrm{~mA}, 20 \mathrm{~min}$. After the electrophoresis time, the microgels were neutralized by placing them twice in a Petri dish with Tris-base (pH 7.0) $5 \mathrm{~mL}$ for $2 \mathrm{~min}$. The microgels dried at room temperature and stained with $50 \mathrm{~mL}$ of $25 \mathrm{mM}$ ethidium bromide [16]. The genotoxic damage was evaluated by observing the microgels on a fluorescence microscope. All the experiments were tested in triplicate.

\section{Statistical Analysis}

Significant differences between groups were evaluated by twoway ANOVA and a tukey pos hoc test [17].

\section{Results}

\section{Evaluation of N-Acetylcysteine Innocuity}

In order to evaluate NAC innocuity, three different NAC doses in human lymphocytes were tested (Figure 1). The results did not indicate significant difference compared against the negative control (PBS 1X) at $500 \mu \mathrm{M}$ and $1000 \mu \mathrm{M}$. Even though NAC at 1500 $\mu \mathrm{M}$ had significant differences in regard to the negative control, such dose did not generate the same DNA damage as the positive control $\left(\mathrm{H}_{2} \mathrm{O}_{2}\right)(\mathrm{p}<0.05)$. It was decided to use $1000 \mu \mathrm{M}$ for the experiments that followed.

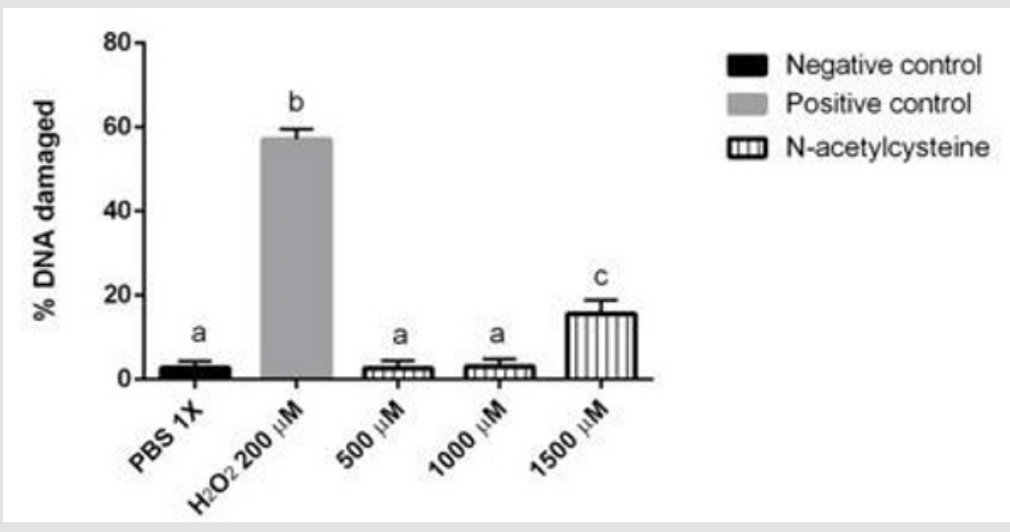

Figure 1: Evaluation of NAC genotoxic effect or innocuity at different concentrations. The innocuity of NAC was compared with the Positive and negative control are shown. Different letters denote values that are statistically different by one-way ANOVA analysis followed by a Tukey's multiple comparison test. P $<0.05$ was considered significant. Bars represent SD (standard deviation).

\section{Copper Sulphate Genotoxicity}

Different $\mathrm{Cu}_{2} \mathrm{SO}_{4}$ doses were tested, and it was observed a significant difference in $50 \mu \mathrm{M}, 100 \mu \mathrm{M}$ and $200 \mu \mathrm{M}$ compared to negative control. These results indicate the DNA damage in a dose dependent manner (Figure 2). Despite the fact that $\mathrm{Cu}_{2} \mathrm{SO}_{4}$ at $50 \mu \mathrm{M}$ and $100 \mu \mathrm{M}$ were significantly different from the negative control, these doses do not generate the same damage $(\mathrm{p}<0.05)$ as the positive control. Only copper sulphate at $200 \mu \mathrm{M}$ caused the same damage ( $\mathrm{p}>0.05$ ) as positive control and for that reason $\mathrm{Cu}_{2} \mathrm{SO}_{4}$ $200 \mu \mathrm{M}$ was used to test the effect of NAC in the DNA repair.

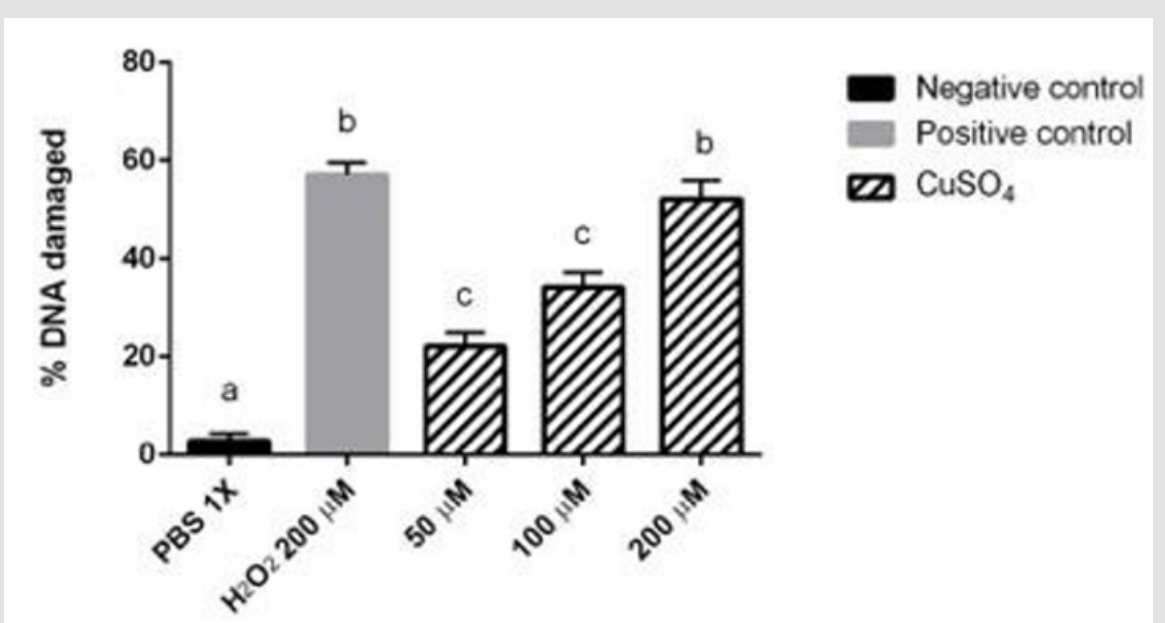

Figure 2: Evaluation of the genotoxic effect of $\mathrm{Cu}_{2} \mathrm{SO}_{4}$ at different concentrations. The genotoxic effect of $\mathrm{Cu}_{2} \mathrm{SO}$ was compared with the Positive and negative control are shown. Different letters denote values that are statistically different by one-way ANOVA analysis followed by a Tukey's multiple comparison test. $(\mathrm{P}<0.05)$. Bars represent SD (standard deviation). 


\section{N-Acetylcysteine Effect on DNA Repair}

In order to study the effect on DNA repair, $\mathrm{N}$-acetylcysteine $1000 \mu \mathrm{M}$ and $\mathrm{Cu}_{2} \mathrm{SO}_{4} 200 \mu \mathrm{M}$ were used. Lymphocytes treated with $\mathrm{Cu}_{2} \mathrm{SO}_{4} 200 \mu \mathrm{M}$ induced 57\% damage to DNA. On the other hand, lymphocytes that were treated for $2 \mathrm{~h}$ with $\mathrm{Cu}_{2} \mathrm{SO}_{4} 200 \mu \mathrm{M}$ and then $2 \mathrm{~h}$ with NAC $1000 \mu \mathrm{M}$, showed a $25.5 \%$ decrease on DNA damage (Figure 3 ). It is interesting to notice that although the DNA damage had a significant difference compared to the negative control $(\mathrm{p}<0.05)$, subsequent treatment with NAC after the DNA damage, significant decreased in comparison to the positive control and $\mathrm{Cu}_{2} \mathrm{SO}_{4} 200 \mu \mathrm{M}$ by itself $(\mathrm{p}<0.05)$. The genotoxic effect and DNA repair analyzed by comet assay is shown in Figure 4. Figure 4A demonstrates a negative control; Figure 4B exhibits positive control; Figure 4C shows NAC $1000 \mu \mathrm{M}$; Figure 4D indicates $\mathrm{Cu}_{2} \mathrm{SO}_{4}$ $200 \mu \mathrm{M}$ genotoxicity; and Figure 4E proved the NAC effect on the DNA repair.

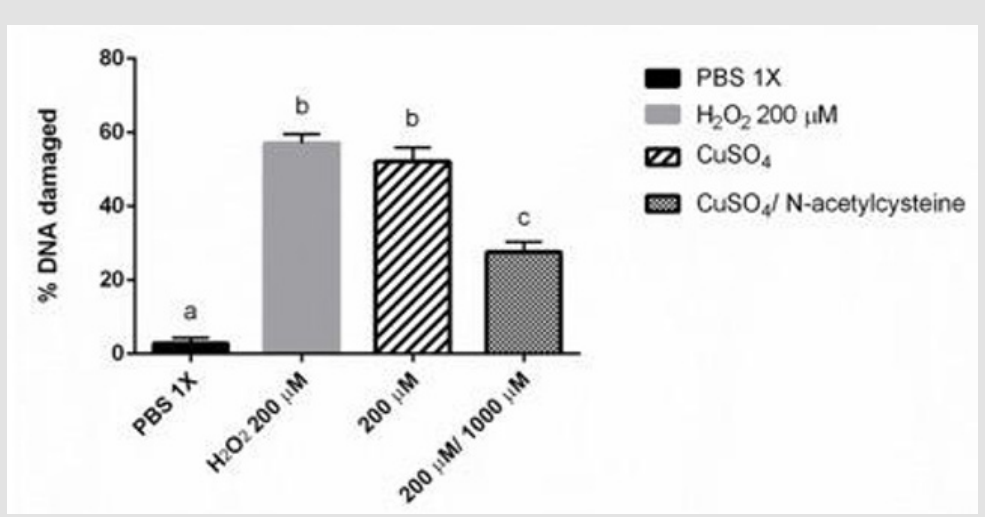

Figure 3: $\mathrm{N}$-acetylcysteine effect on DNA repair. The genotoxic effect of $\mathrm{Cu}_{2} \mathrm{SO}_{4}$ is shown both, alone and together with $\mathrm{N}$-acetylcysteine. $\mathrm{N}$-acetylcysteine was added after $2 \mathrm{~h}$ of lymphocyte treatment with $\mathrm{Cu}_{2} \mathrm{SO}_{4}$ and the effect on DNA repair is shown. Positive and negative control are shown too. Different letters denote values statistically different by one- way ANOVA analysis followed by a Tukey's multiple comparison test. $\mathrm{P}<0.05$ was considered significant. Bars represent SD (standard deviation).

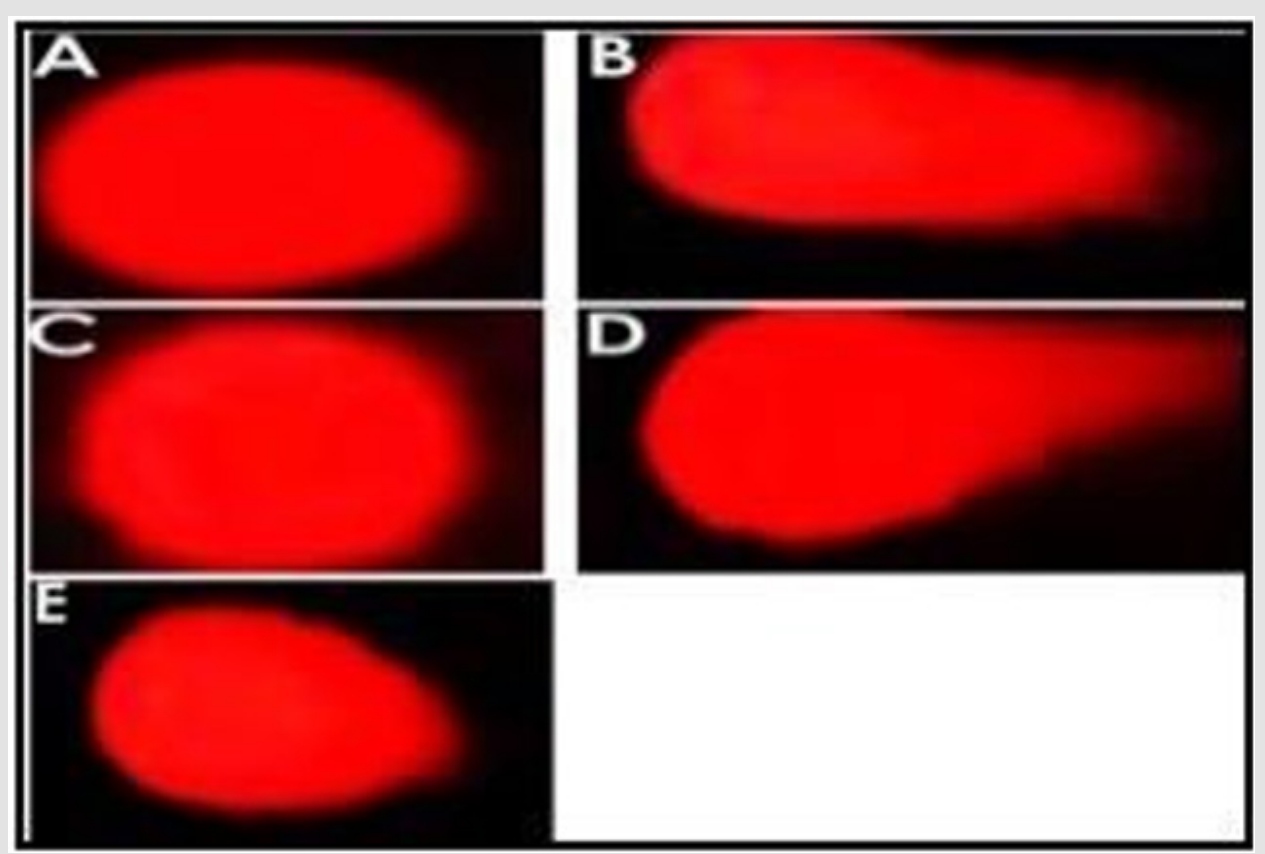

Figure 4: Evaluation of DNA damage by comet assay. The presence and length or absence of the comet tail can be observed in each figure.
A. PBS $1 X$.
B. $\mathrm{H}_{2} \mathrm{O}_{2} 200 \mu \mathrm{M}$.
C. N- acetylcysteine $1000 \mu \mathrm{M}$.
D. $\mathrm{CuSO}_{4} 200 \mu \mathrm{M}$.
E. $\mathrm{CuSO}_{4} 200 \mu \mathrm{M} / \mathrm{NAC} 1000 \mu \mathrm{M}$. 


\section{Discussion}

$\mathrm{CuSO}_{4}$ has been reported to cause DNA damage, which is referred to as genotoxicity. It has been documented that copper concentrations are significantly elevated in several types of malignancies, and in turn, it leads to ROS increase and redox imbalance. The DNA damage caused by ROS was accepted as the beginning of cancer development [18]. In this study, the genotoxic effect of $\mathrm{CuSO}_{4}$ was evaluated by comet assay. Three $\mathrm{CuSO}_{4}$ concentrations $(50 \mu \mathrm{M}, 100 \mu \mathrm{M}, 200 \mu \mathrm{M})$ induced DNA damage with significant difference compared to negative control, being the concentration $200 \mu \mathrm{M}$ the most genotoxic. According to previous reports, the main genotoxic effect by $\mathrm{CuSO}_{4}$ is due to the increase of reactive oxygen species (ROS) [19] which promotes that endogenous antioxidants and DNA repair systems get overwhelmed by redox imbalance as indicates previous study by Kermanizadeh, et al. [20]. Cells contain a variety of DNA repair enzymes to repair oxidant-induced DNA damage but, according to Mesquita, et al. those enzymes do not function properly in the presence of high amounts of ROS increased by $\mathrm{CuSO}_{4}[21]$.

Our results are consistent with previous reports about copper genotoxicity in marine animals [22] and mice [23] in which copper induced ROS increase and oxidative DNA damage in vivo. The next goal was to determine if NAC is innocuous and if it mediates the DNA repair and the NAC $500 \mu \mathrm{M}$ and $1000 \mu \mathrm{M}$ did not show significant differences on the DNA damage compared to the negative control, which indicates cellular innocuousness. Given the fact that lymphocytes treated first with $\mathrm{CuSO}_{4} 200 \mu \mathrm{M}$ and then with NAC $1000 \mu \mathrm{M}$ showed lower DNA damage compared to those treated only with $\mathrm{CuSO}_{4}$, such results suggest that the NAC $1000 \mu \mathrm{M}$ exerts an adjuvant effect on DNA repair as well a DNA protection as indicated Xie, et al. [8]. A possible explanation for DNA repair by NAC could be the restoration of redox balance due to its antioxidant effect as indicated by previous reports [11,24]. In this case, NAC regulates the redox balance, for the correct function of the enzymatic defense mechanisms, which contains superoxide dismutase, catalase and glutathione-peroxidase as the most important antioxidant enzymes [25].

At the other extreme, antioxidant protection can be nonenzymatic [26]. Glutathione is a non-enzymatic antioxidant composed of L-glutamate, L-cysteine and L-glycine, and is the predominant intracellular non-protein sulfhydryl in a wide range of cells [27]. NAC can promote Glutathione synthesis, and both play a critical role in cellular defense and helps maintain structural and functional viability of proteins, same as DNA repair enzymes, by means of reducing the amounts of ROS by their reducing property through its thiol-disulfide exchange activity [28]. Furthermore, the reduction of ROS leads to the decrease of oxidative DNA damage and enables the enzyme to mediate the DNA repair [29]. It is possible to determine the mechanism by which NAC exerts its action as DNA repair compound by measuring ROS levels and enzymatic activity on DNA repair after treatment with $\mathrm{CuSO}_{4} / \mathrm{NAC}$.

\section{Conclusion}

The conclusion of our collected data indicates that NAC is innocuous to $500 \mu \mathrm{M}$ and $1000 \mu \mathrm{M}$, and $\mathrm{CuSO}_{4}$ induces DNA damage in a concentration dependent manner in human lymphocytes. The DNA damage caused by $\mathrm{CuSO}_{4}$ can be repaired by NAC. Based upon these findings, NAC should be evaluated for its innocuity in further studies as well as a source of Geno protective and auxiliary compounds in DNA repair in several other types of cells.

\section{Recommendations}

We recommend testing a large range of $\mathrm{NAC}$ and $\mathrm{CuSO}_{4}$ concentrations in different cancer and normal cell lines. However, the measure of ROS levels and the evaluation of enzymatic activity of the DNA repair system could provide additional evidence about the NAC and $\mathrm{CuSO}_{4}$ Geno protective and genotoxic mechanisms, respectively.

\section{Acknowledgement}

We thank FOFI-UAQ 2018 DPI-464/2018 and English edition to Agustín Ruiz Esparza Y Ballesteros, M.A., C2 Oxford College International, Oxfordshire, U.K.

\section{References}

1. Alhusaini A, Fadda L, Hassan I, Ali HM, Alsaadan N, et al. (2018) Liposomal Curcumin Attenuates the Incidence of Oxidative Stress, Inflammation, and DNA Damage Induced by Copper Sulfate in Rat Liver. Dose-Response 16(3): 155932581879086.

2. Klaudia Jomova, Michael Lawson, Lenka Drostinova, Peter Lauro, Patrik Poprac, et al. (2017) Protective Role of Quercetin against Copper(II)Induced Oxidative Stress: A Spectroscopic, Theoretical and DNA Damage Study. Food and Chemical Toxicology 110: 340-350.

3. Upadhyayula Sai Srinivas, Bryce WQ Tan, Balamurugan A Vellayappan, Anand D Jeyasekharan (2019) ROS and the DNA Damage Response in Cancer. Redox Biology 25: 101084.

4. İșeri ÖD, Körpe DA, Yurtcu E, Sahin FI, Haberal M (2011) CopperInduced Oxidative Damage, Antioxidant Response and Genotoxicity in Lycopersicum Esculentum Mill. and Cucumis Sativus L. Plant Cell Reports 30(9): 1713-1721.

5. H Zubair, HY Khan, A Sohail, S Azim, M F Ullah, et al. (2013) Redox Cycling of Endogenous Copper by Thymoquinone Leads to ROS-Mediated DNA Breakage and Consequent Cell Death: Putative Anticancer Mechanism of Antioxidants. Cell Death \& Disease 4(6): e660.

6. Pappuswamy Manikantan, V Balachandar, K Sasikala (2010) DNA Damage in Workers Occupationally Exposed to Lead, Using Comet Assay. International Journal of Biology 2(1).

7. Alagamuthu Karthick Kumar, Vellingiri Balachandar, Meyyazhagan Arun, Shafi Ahammed Khan Mustaq Ahamed, Shanmugam Suresh Kumar, et al. (2013) A Comprehensive Analysis of Plausible Genotoxic Covariates Among Workers of a Polyvinyl Chloride Plant Exposed to Vinyl Chloride Monomer. Archives of Environmental Contamination and Toxicology 64 (4): 652-658.

8. Chuan Xie, Jian Yi, Jing Lu, Muwen Nie, Meifang Huang, et al. (2018) N- Acetylcysteine Reduces ROS-Mediated Oxidative DNA Damage and PI3K/Akt Pathway Activation Induced by Helicobacter Pylori Infection. Oxidative Medicine and Cellular Longevity 2018: 1874985. 
9. Yi Xie, Hong Zhang, Ji Fang Hao, Rong Qiu (2009) Effect of N-Acetylcysteine on $(12) \mathrm{C}(6+)$ Ion Irradiation-Induced Lymphocytes DNA Damages and Immunity Changes in Mice. Journal of Radiation Research 50 (6): $567-$ 571.

10. Ansari EA, Khan AZ, Riaz M (2018) Protective Effect of Carnosine and $\mathrm{N}$-Acetylcysteine against Sodium Nitrite-Induced Oxidative Stress and DNA Damage in Rat Intestine. Environmental Science and Pollution Research 25(20): 19380-19392.

11. Ruhi Turkmen, Yavuz Osman Birdane, Hasan Huseyin Demirel, Hidayet Yavuz, Mustafa Kabu, et al. (2019) Antioxidant and Cytoprotective Effects of N-Acetylcysteine against Subchronic Oral Glyphosate-Based Herbicide-Induced Oxidative Stress in Rats. Environmental Science and Pollution Research 26(11): 11427-11437.

12. Min Zhang, HaiLing Xia, Min Yu, LiJin Zhu, Li Ju, et al. (2018) N-Acetylcysteine Prevents Cytotoxic Effects Induced by Man-Made Mineral Fibers in a Human Bronchial Epithelial Cell Line. Toxicology In Vitro 53: 200-207.

13. Roland Wunderlich, Paul Friedrich Ruehle, Lisa Deloch, Kristian Unger, Julia Hess, et al. (2017) Interconnection between DNA Damage, Senescence, Inflammation and Cancer. Frontiers in Bioscience 22: 348369.

14. Jinchuan Hu, Christopher P Selby, Sheera Adar, Ogun Adebali, Aziz Sancar (2017) Molecular Mechanisms and Genomic Maps of DNA Excision Repair in Escherichia Coli and Humans. Journal of Biological Chemistry 292(38): 15588-15597.

15. Ruijin Li, Lifang Zhao, Li Zhang, Minghui Chen, Jing Shi, et al. (2017) Effects of Ambient PM 2.5 and 9-Nitroanthracene on DNA Damage and Repair, Oxidative Stress and Metabolic Enzymes in the Lungs of Rats. Toxicology Research 6(5): 654-663.

16. Xinzhu Pu, Zemin Wang, James E Klaunig (2015) Alkaline Comet Assay for Assessing DNA Damage in Individual Cells. Curr Protoc Toxicol 65(1): 3.12.1-3.12.11

17. William Mendenhall, Robert J Beaver, Barbara M Beaver (2012) Introduction to Probability and Statistics. Edited by Thomson Books/ Cole. (14 ${ }^{\text {th }}$ Edn.). Texas, USA.

18. Seema Kumari, Anil Kumar Badana, Murali Mohan G, Shailender G, RamaRao Malla (2018) Reactive Oxygen Species: A Key Constituent in Cancer Survival. Biomarker Insights 13: 117727191875539.

19. Emad A Hashish, Shimaa A Elgaml (2016) Hepatoprotective and Nephroprotective Effect of Curcumin Against Copper Toxicity in Rats. Indian Journal of Clinical Biochemistry 31(3): 270-277.

ISSN: 2574-1241

DOI: $10.26717 / B J S T R .2020 .29 .004776$

Guadalupe García Alcocer. Biomed J Sci \& Tech Res

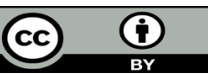

This work is licensed under Creative Commons Attribution 4.0 License

Submission Link: https://biomedres.us/submit-manuscript.php
20. Ali Kermanizadeh, Caroline Chauché, David M Brown, Steffen Loft, Peter Møller (2015) The Role of Intracellular Redox Imbalance in Nanomaterial Induced Cellular Damage and Genotoxicity: A Review. Environmental and Molecular Mutagenesis 56 (2): 111-124.

21. Andreia F Mesquita, Sérgio M Marques, João C Marques, Fernando JM Gonçalves, Ana MM Gonçalves (2019) Copper Sulphate Impact on the Antioxidant Defence System of the Marine Bivalves Cerastoderma Edule and Scrobicularia Plana. Scientific Reports 9(1): 16458.

22. Chelomin Victor P, Valentina V Slobodskova, Maksim Zakhartsev, Sergey Kukla (2017) Genotoxic Potential of Copper Oxide Nanoparticles in the Bivalve Mollusk Mytilus Trossulus. Journal of Ocean University of China 16(2): 339-345.

23. Daniel Prá, Silvia Isabel Rech Franke, Raquel Giulian, Maria Lúcia Yoneama, Johnny Ferraz Dias, et al. (2008) Genotoxicity and Mutagenicity of Iron and Copper in Mice. BioMetals 21(3): 289-297.

24. Aldini G, Altomare A, Baron G, Vistoli G, Carini M, et al. (2018) $\mathrm{N}$-Acetylcysteine as an Antioxidant and Disulphide Breaking Agent: The Reasons Why. Free Radical Research 52(7): 751-762.

25. Long He, Ting He, Shabnam Farrar, Linbao Ji, Tianyi Liu, et al. (2017) Antioxidants Maintain Cellular Redox Homeostasis by Elimination of Reactive Oxygen Species. Cellular Physiology and Biochemistry 44(2): 532-553.

26. Baumeister Philipp, Thomas Huebner, Maximilian Reiter, Sabina Schwenk Zieger, Ulrich Harréus (2009) Reduction of Oxidative DNA Fragmentation by Ascorbic Acid, Zinc and N- Acetylcysteine in Nasal Mucosa Tissue Cultures. Anticancer Research 29(11): 4571-4574.

27. Elie Hatem, Nadine El Banna, Meng Er Huang (2017) Multifaceted Roles of Glutathione and Glutathione-Based Systems in Carcinogenesis and Anticancer Drug Resistance. Antioxidants \& Redox Signaling 27(15): 1217-1234.

28. Shi Yong Sun (2010) N-Acetylcysteine, Reactive Oxygen Species and Beyond. Cancer Biol Ther 9(2): 109-110.

29. Finn Nnenna Adimora, Melissa Lambeth Kemp (2012) Pro-Oxidant and Antioxidant Effects of N-Acetylcysteine Regulate Doxorubicin-Induced NF-Kappa B Activity in Leukemic Cells. Molecular BioSystems 8(2): 650662.

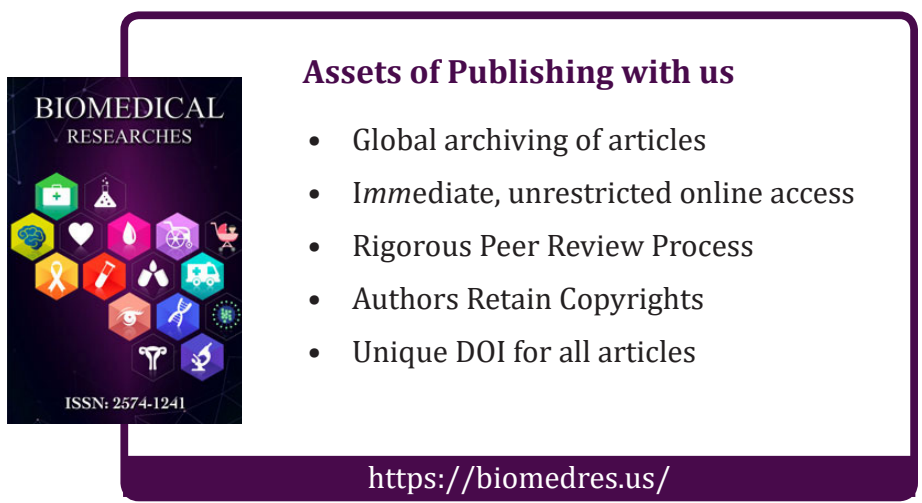

